\title{
Renesansowe zbroje płytowe z napierśnikiem bombiastym w dawnym księstwie pomorskim w świetle wybranych zabytków sztuki
}

\begin{abstract}
Słowa kluczowe: Pomorze, nowożytność, książęta pomorscy, ikonografia, zbroje płytowe Key words: Pomerania, modern times, Pomeranian dukes, iconography, plate armour
\end{abstract}

Do dnia dzisiejszego zachowało się wiele źródeł ikonograficznych dokumentujących stan renesansowego rynsztunku. Oprócz obiektów numizmatycznych, sfragistycznych lub heraldycznych należą do nich zabytki sztuki. W pełnym uzbrojeniu głównie przedstawiani byli władcy i członkowie stanów, co miało świadczyć o ich wysokiej pozycji społecznej. Artyści wykonujący te wizerunki najczęściej wykorzystywali autentyczne uzbrojenie, dzięki czemu powstawał wiarygodny materiał źródłowy ${ }^{1}$. Należy jednak zaznaczyć, że poziom odwzorowania uzbrojenia w ikonografii nie był jednolity.

Na podstawie analizy bronioznawczej zabytków sztuki badacz uprawniony bywa do wysunięcia odpowiednich wniosków ${ }^{2}$. Dotychczas podjęto niewiele prób syntetycznego opracowania uzbrojenia na podstawie zabytków sztuki w dawnym księstwie pomorskim ${ }^{3}$. Temat ten marginalnie poruszany był w niektórych publikacjach, głównie w inwentarzach zabytków ${ }^{4}$, a także w pracach badaczy zajmujących się zagadnieniami łączącymi się z problemami uzbrojenia w ikonografii. Są to prace Marii Glińskiej, dotyczące plastyki kamiennej ${ }^{5}$, Marcina Wisłockiego o sztuce protestanckiej ${ }^{6}$ i Marcina Majewskiego o brązowej płycie nagrobnej Petera von Kameke?

W ostatnich stuleciach średniowiecza coraz większe znaczenie miało zastosowanie na polu bitwy broni drzewcowej, miotającej i palnej. Spowodowało to zmiany w uzbrojeniu ochronnym, a w efekcie przyczyniło się do rozpowszechnienia pełnej zbroi płytowej ${ }^{8}$. Z cza-

1 Żygulski Z. 1982, s. 169.

2 Najlepiej pokazał to ostatnio Tobias Capwell (Capwell T. 2015). Spośród prac powstałych w głównej mierze na podstawie źródeł ikonograficznych, a zwłaszcza zabytków sztuki, należy również wymienić: Kajzer L. 1976; Wawrzonowska Z. 1976; Cieśla M. 2008.

3 Por. Puławski A. 2016a; Puławski A. 2016b; Puławski A. 2017.

${ }^{4} \mathrm{~Np}$. w inwentarzach Hugo Lemckego.

5 Glińska M. 1973.

${ }^{6}$ Wisłocki M. 2005.

${ }^{7}$ Majewski M. 2005. Temat uzbrojenia w dawnym księstwie pomorskim na podstawie innych źródeł ikonograficznych omawiany był w publikacjach: Wybranowski D. 1987; Wybranowski D. 1993; Wybranowski D. 2004; Maciejowski M. 2000.

${ }^{8}$ Proces ewolucji i rozpowszechnienia zbroi płytowej trwał kilkaset lat. Według nowszej literatury zbroja płytowa wykształciła się w połowie XIV w. (Richardson T. 2016, s. 69). Jednym z najsłynniejszych ośrodków płatnerskich w średniowieczu był Mediolan (Żygulski Z. 1982, s. 107). 
sem zbroja ta ewoluowała, zmieniały się jej kształty, poszczególne elementy konstrukcyjne i style dekoracji, a także jej przeznaczenie. Oprócz zbroi bojowej stosowano również turniejowe i paradne (ceremonialne), które były uzbrojeniem ekskluzywnym. Wiodące ośrodki, w których czynne były warsztaty płatnerskie w ówczesnej Europie, znajdowały się na terenie Włoch (np. Mediolan, Mantua, Rzym) i Niemiec (np. Augsburg, Landshut, Norymberga, Innsbruck, Wittenberga, Drezno, Annaberg, Kolonia, Brunszwik). Z czasem również w innych krajach zaczęli działać płatnerze wytwarzający zbroje wysokiej jakości, np. w Anglii (Greenwich, Sauthwark) i Szwecji (Arboga) ${ }^{9}$. Patronowali im feudałowie, pragnący posiadać uzbrojenie najwyższej klasy.

Dla klasyfikacji zbroi istotnym elementem jest napierśnik. Pierwszym typem napierśnika używanym w renesansie był napierśnik bombiasty (kolisty), stosowany w Europie do lat czterdziestych XVI w. ${ }^{10}$ Charakteryzował się on wciętym klinem i wąskim w talii fartuchem, w niektórych przypadkach zachodzącym pod pierś lub na nią, z przymocowanymi taszkami ${ }^{11}$. Ten typ napierśnika ewoluował w typ tzw. tapul, gdzie krągłe wybrzuszenie napierśnika bombiastego przekształciło się w ostry występ. Zbroje płytowe z napierśnikiem bombiastym używane były również na Pomorzu, co potwierdziły moje wcześniejsze badania ${ }^{12}$.

Podstawę niniejszego artykułu stanowią zabytki sztuki prezentujące przedstawicieli społeczeństwa pomorskiego ${ }^{13}$. Większość wizerunków powstała za życia osób odwzorowanych bądź krótko po ich śmierci. Wyjątek stanowi kamienna płyta z 1543 r. przedstawiająca Barnima III w renesansowej zbroi płytowej kanelowanej (ryc. 1; nr kat. 1). Sposób zaprezentowania pancerza jest tu bardzo wierny, co jest niezmiernie przydatne dla badacza uzbrojenia historycznego.

Analizie poddano jedenaście obiektów. Wszystkie wizerunki to płaskorzeźby, dziesięć wykonano w kamieniu (ryc. 1-4, 6-11; nr kat. 1-4, 6-11) a jeden w drewnie (ryc. 5a-5b; nr kat. 5). Trzy zabytki stanowią płyty fundacyjne (ryc. 1-2, 8; nr kat. 1-2, 8), siedem nagrobne (ryc. 3-4, 6-7, 9-11; nr kat. 3-4, 6-7, 9-11), zaś jeden obiekt to epitafium (ryc. 5a-5b; nr kat. 5). Trzy spośród tych wizerunków przedstawiają książąt pomorskich (ryc. 1-2, 5a-5b; nr kat. 1-2, 5), osiem pomorską szlachtę (ryc. 3-4, 6-11; nr kat. 3-4, 6-11). Do dziś przetrwało osiem z badanych obiektów (ryc. 1-3, 7-11; nr kat. 1-3, 7-11), pozostałe znane są dzięki dokumentacji fotograficznej (ryc. 4-6; nr kat. 4-6). Omawiane wizerunki powstały z myślą o umieszczeniu ich w miejscach traktowanych jako pomniki rodowe, takich jak rezydencje (ryc. 1-2, 8; nr kat. 1-2, 8) i świątynie (ryc. 3-7, 9-11; nr kat. 3-7, 9-11). Z zabytków, które przetrwały, pięć znajduje się obecnie w swojej pierwotnej lokalizacji (ryc. 3, 8-11; nr kat. 3, 8-11), zaś trzy zostały przeniesione (ryc. 1-2, 7; nr kat. 1-2, 7). Omawiane w niniejszej pracy wyobrażenia stanowią punkt wyjścia do badań nad pomorską zbroją płytową w pierwszych dekadach XVI w.

Poziom artystyczny uwzględnionego materiału ikonograficznego jest różny. Na szczególną uwagę zasługuje epitafium Bogusława X z ok. 1550 r. (ryc. 5a-5b; nr kat. 5). Odwzorowane tu, pokrywające jego zbroję dekoracje są dokładne, dzięki czemu są bardzo użyteczne dla badań bronioznawczych. Odmienna sytuacja dotyczy płyty nagrobnej Arenta von Wopersnow z $1549 \mathrm{r}$. (ryc. 3; nr kat. 3). Pod względem artystycznym zabytek cechuje niezbyt wysoki poziom wykonania $^{14}$, a np. sposób odwzorowania hełmu wyklucza go z jakiejkolwiek analizy.

Badania nad użyciem zbroi płytowych z napierśnikiem bombiastym w szesnastowiecznym księstwie pomorskim mogą stanowić znaczące dopełnienie wiedzy o stosowaniu tego typu

${ }_{9}$ Cieśla M. 2008, s. 13-14; Cieśla M. 2011, s. 283-309.

10 Żygulski Z. 1982, s. 155.

11 Blair C. 1958, s. 119.

12 Puławski A. 2016b, s. 185, 194-200; Puławski A. 2017, s. 81.

${ }_{13} \mathrm{~W}$ artykule zrezygnowano z omówienia zbroi postaci biblijnych przedstawionych w pomorskiej ikonografii.

${ }^{14}$ Glińska M. 1973, s. 328. 
uzbrojenia w basenie Morza Bałtyckiego, a zarazem istotny przyczynek do poznania kultury materialnej elity jednego z ważnych krajów północy Rzeszy.

Analizując uwzględniony materiał ikonograficzny należy odnieść się do zbroi jako całości, określając ich kształty i styl. Zbroje gotyckie charakteryzowały się smukłą sylwetką, ostrością kształtów i wydłużonymi formami, renesansowe zaś szerokością i krągłością, a także złagodzeniem konturów ${ }^{15}$. Fundamentem tego procesu były zmiany w zakresie świeckiego ubioru, którego styl przenikał do uzbrojenia.

Jedną z najbardziej charakterystycznych osłon ciała w okresie renesansu była zbroja kanelowana, określana również maksymiliańską ${ }^{16}$. Było to uzbrojenie ekskluzywne, a zarazem mające zastosowanie bojowe. Na analizowanych źródłach ikonograficznych zbroja tego typu występuje czterokrotnie (ryc. 1-3, 6; nr kat. 1-3, 6). Powierzchnia zbroi maksymiliańskiej była formowana w charakterystyczne zespoły żłobków (kanelur) lub żeber (karbków), które oprócz walorów estetycznych wzmacniały jej odporność i sztywność, bez zwiększenia masy ${ }^{17}$. Zbroje te były popularne w pierwszej połowie XVI w. Ich zaokrąglone kontury i horyzontalne linie były zgodne z tendencjami w ówczesnej modzie męskiej. To samo tyczy się trzewików „krowie pyski”, które były odpowiednikiem charakterystycznych płaskich butów z szerokimi przodami, lub taszek odpowiadających bufiastym bądź kulistym spodniom, sięgającym do pół uda lub niżej ${ }^{18}$.

W badanym okresie oprócz zbroi w stylu maksymiliańskim używano także zbroi o takich samych harmonijnych proporcjach, lecz gładkich (ryc. 4, 7-9, 10-11; nr kat. 4, 7-9, 10-11). Na pierwszym z wizerunków tego typu zbroja zaopatrzona jest w marszczoną spódniczkę. Ze źródeł pisanych wiadomo, że książę pomorski Jerzy I posiadał całkowicie gładką zbroję jeździecką (Kürris) wykonaną przez augsburskiego płatnerza, Kolmana Helmschmida, którą otrzymał w darze od Albrechta Hohenzollerna ${ }^{19}$.

Zdecydowana większość omawianych egzemplarzy to zbroje bojowe. Jednakże podczas analizy decydująca nie jest wyłącznie funkcja zbroi - bojowa, turniejowa lub paradna, lecz istotny jest też jej garnitur, czyli pełny komplet elementów płytowych, z których można było złożyć kilka rodzajów zbroi, w zależności od zapotrzebowania ${ }^{20}$. Elementy wskazujące na używanie garnituru zbroi widoczne są na płycie nagrobnej Jacoba von Küssowa (ryc. 10; nr kat. 10). $\mathrm{Na}$ lewym naramienniku szlachcica umieszczony jest bowiem dodatkowy taki element. Dzięki zastosowaniu naramiennika wzmacniającego z płotem, lekka zbroja polowa (Feldküriss) była przekształcana w polową kopijniczą (Küriss). Potwierdzeniem tego jest jedna tarczka opachowa (z prawej strony), będąca częścią lekkiej zbroi polowej ${ }^{21}$. Wymienione poniżej analogie pomiędzy zbroją zaprezentowaną na epitafium Bogusława X (ryc. 5a-5b; nr kat. 5), a zbroją przechowywaną w Niemieckim Muzeum Historycznym w Berlinie sugerują możliwość posiadania także przez tego władcę garnituru zbroi.

Wśród prezentowanych zabytków są także zbroje kostiumowe (ryc. 4-5b; nr kat. 4-5). Szczególne walory pod tym względem cechują uzbrojenie Bogusława X. Dzięki dużej precyzji odwzorowania można stwierdzić jej wysoki kunszt, zaś sposób zdobienia jest przykładem wpływu ówczesnego stylu w ubiorze męskim na ornamentykę w płatnerstwie. Mowa tu o eks-

15 Żygulski Z. 1982, s. 107, 152.

${ }^{16}$ Nie zostało potwierdzone, by cesarz Maksymilian I (1459-1519) przyczynił się do powstania tego stylu w płatnerstwie. Termin ,zbroja maksymiliańska” wprowadził w 1840 r. Florent Gillea, por. Cieśla M. 2008 , s. 15.

17 Żygulski Z. 1982, s. 151.

18 Żygulski Z. 1972, s. 69-70, 75.

${ }_{19}$ Gamber O. 1975, s. 9; Cieśla M. 2015b, s. 13.

${ }^{20}$ Bołdyrew A. 2005, s. 97. Zagadnienie garnituru zbroi szczegółowo omawia Fuiński Z. 1988.

${ }^{21}$ Fuiński Z. 1988, ryc. 94. 
trawaganckiej modzie landsknechtów. Dzięki przekazom ikonograficznym można również wskazać analogie w strojach samego Bolesława X. Na portrecie olejnym wykonanym na drewnie książę ubrany jest w płaszcz wierzchni pokryty motywem podobnym jak zbroja na jego epitafium $^{22}$. Dekoracje pokrywające pancerz odwzorowany na wizerunku Gryfity umożliwiły także identyfikację zbroi wchodzącej w skład zbiorów Muzeum w Berlinie. Bogusław X (1454-1523) był władcą goszczącym na europejskich dworach. W latach 1496-1498 odbył wyprawę na niemiecki dwór królewski, do Ziemi Świętej i Rzymu, podczas której stoczył bitwę morską z Turkami ${ }^{23}$. Osobiście zetknął się z przepychem europejskich władców, także w zakresie stosowanego uzbrojenia. W 1497 r. w dowód uznania książę otrzymał od papieża Aleksandra VI Borgii złoty miecz z bogato dekorowaną pochwą ${ }^{24}$. Był to element godny nie tylko władcy, ale i obrońcy chrześcijaństwa. Takie cechy ma uzbrojenie ochronne, które odwzorowano na płycie nagrobnej.

Zbroje płytowe z napierśnikiem bombiastym przedstawione na opisywanych źródłach ikonograficznych w większości potwierdzają ogólny stan wiedzy na temat tego typu uzbrojenia używanego w pierwszych dekadach XVI stulecia. Zarazem dają one podstawę do przypuszczenia, że Pomorzanie używali zbroi nie różniących się standardem od uzbrojenia ochronnego elit innych regionów, np. Śląska ${ }^{25}$. Wyjątkiem jest zbroja z epitafium Bogusława X, której analiza dostarczyła też innych, znaczących wniosków.

Omawiany typ zbroi był stosowany na wielu dworach panujących oraz szlacheckich. Był jednym z etapów w rozwoju pełnej zbroi płytowej, który przypadł na okres od połowy XV w. do połowy XVII w. Na uwzględnionych wizerunkach był on czymś więcej niż tylko drogim strojem. Tak jak herb czy miecz zbroja również świadczyła o wysokim statusie uwiecznionej postaci. I chociaż ikonografia to tylko jedno z wielu źródeł w studiach nad skalą użytkowania na Pomorzu zbroi płytowych z napierśnikiem bombiastym, to analizowane zabytki nie tylko uzupełniają stan wiedzy na temat pomorskiej wojskowości, ale także są cennym materiałem do dalszych badań.

Na szczególne omówienie zasługuje wspomniana już zbroja kostiumowa z epitafium księcia Bogusława X (ryc. 5a-5b; nr kat. 5) ${ }^{26}$. Zbroją kostiumową określa się ochronę ciała wykonaną z metalu, która na powierzchni (lub tylko na niektórych częściach) ma dekorację w formie współczesnego kostiumu lub pancerz bez takiego zdobienia, ale wyposażony w spódniczkę ${ }^{27}$. Zbroję Gryfity charakteryzuje dekoracja tzw. dmuchana i cięta na napierśniku, naramiennikach, opachach i zarękawiu. Na napierśniku grube poziome żłobki połączone są zygzakami. Ornament ten, jak wcześniej odnotowano, jest odbiciem detali obowiązujących w modzie męskiej z tego samego okresu.

${ }^{22}$ Rymar E. 2005, s. 384.

23 Wyprawę szczegółowo analizuje Rymar E. 2004a; Rymar E. 2004 b.

${ }^{24}$ Kantzow T. 2005, s. 101. Miecz został wykonany w pracowni Angelino de Sutri. Po wymarciu Gryfitów broń weszła w posiadanie Hohenzollernów. Obecnie zachowała się jedynie pochwa, natomiast miecz zaginął. Jego kopia znajduje się w Hohenzollernmuseum Schloss w pobliżu Hechingen w Niemczech, Rymar E. 2004a, s. 166-168; Puławski A. 2017, s. 84.

25 Stan uzbrojenia renesansowego na tym terenie dokumentuje Cieśla M. 2008.

${ }^{26}$ Pragnę podziękować dr. Mariuszowi Cieśli z Muzeum Miejskiego Wrocławia za pomoc w identyfikacji zbroi.

27 Cieśla M. 2015a, s. 9.

${ }^{28}$ Według Janiny Kochanowskiej, artysta był również autorem ołtarza i ambony, znajdujących się obecnie w kościele filialnym pw. św. Marii Magdaleny w Sownie (gm. Stargard, pow. stargardzki). Wszystkie trzy dzieła Autorka łączy z fundacją Barnima XI (IX) (por. Kochanowska J. 1995, s. 129-139; Kochanowska J. 1996, s. 110-113; Kochanowska J. 2000, s. 111-115). Hipotezę o fundacji wszystkich obiektów przez tego księcia wysunął też Bethe H. 1937b, s. 32, 110-113. 
Autorem dzieła jest Hans Peisser (Peysser, Beitzer, Beisser) z Gdańska ${ }^{28}$. Rzeźbiarz ten specjalizował się w dekoracjach umieszczanych najczęściej na fryzach i stropach, osiągając wysoki poziom w zakresie detali snycerskich ${ }^{29}$. Szaty i zbroję pomorskiego księcia również wyrzeźbiono z dbałością o szczegóły. Artysta, przebywając na szczecińskim zamku, prawdopodobnie korzystał z dostępu do zbrojowni i wykonując epitafium odwzorował autentyczną zbroję $e^{30}$.

Wśród zachowanych obiektów płatnerstwa europejskiego identycznie zdobiona jest zbroja kostiumowa z kolekcji berlińskiej (Deutsche Historisches Museum, nr inw. W 2327) (ryc. 12). Pochodzenie tego egzemplarza nie zostało pewnie ustalone, choć obecnie jej wykonanie przypisuje się warsztatom południowoniemieckim, a datuje na około 1515 r. Należy jednak nadmienić, że ochrony nóg pochodzą z innego zestawu, co wyłącza je z analizy ${ }^{31}$. Napierśnik zbroi, tak jak na płycie nagrobnej Gryfity, pokryty jest imitującymi cięcia poziomymi żłobkami, połączonymi ze sobą zygzakami. Oryginalne uzbrojenie pokrywają także pasy w kolorze złota, biegnące wzdłuż horyzontalnych żłobków. Taki motyw pokrywa również ochronę rąk, jednak tam dekoracja ta jest bardziej wypukła, czyli tzw. dmuchana i cięta. Jest to spowodowane dostosowaniem ornamentu do elementów konstrukcyjnych osłaniających ręce ${ }^{32}$.

Identyczne zdobienie występuje na folgowanym fartuchu i taszkach, które na epitafium Gryfity są mało widoczne, jedynie fragmentarycznie spod wycięć na poły w kanelowanej spódniczce. Zakładając, że zabytek z berlińskiego muzeum jest uzbrojeniem należącym niegdyś do Bogusława $\mathrm{X}$, na co dobitnie wskazują analogie pomiędzy wyobrażeniem na płaskorzeźbie a oryginałem, może to być poszlaka na

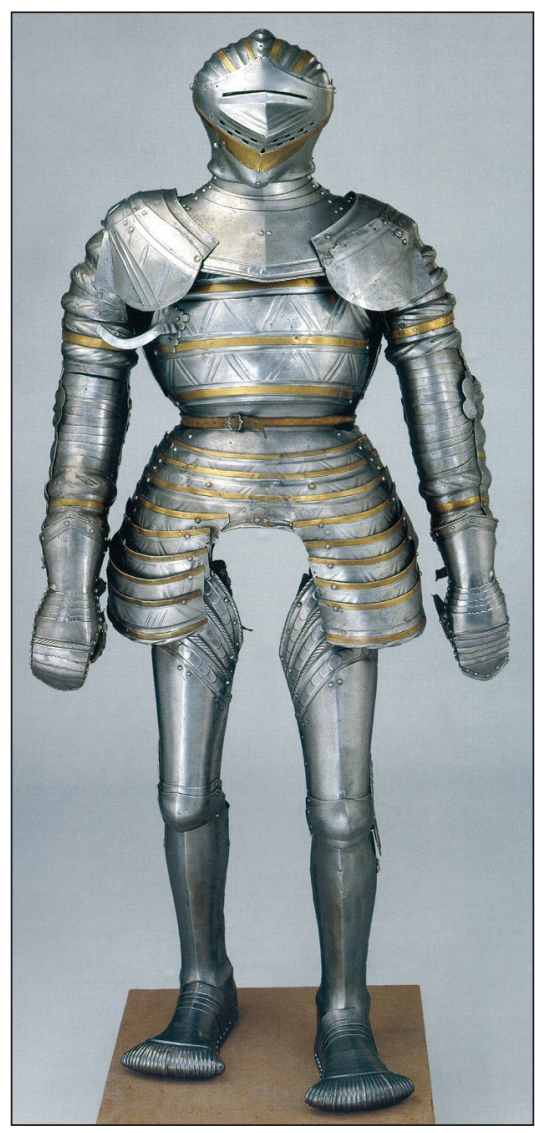

Ryc. 12. Zbroja kostiumowa z ok. $1550 \mathrm{r}$. (za: Burg und Herrschaft. 2010, ryc. 6.12 )

Fig. 12. A costume suit of armour from c. 1550 (after Burg und Herrschaft. 2010, fig. 6.12) temat garnituru zbroi tego księcia. Kolejne podobieństwa dotyczą konstrukcji hełmu. Identyczne są: zasłona typu „wróbli dziób” i dzwon, który dekorują rzędy żłobków, idące równolegle do niskiego grzebienia. Hełm także zdobiony jest złotymi pasami, które na zasłonie przebiegają poziomo pod otworami oddechowymi, zaś na dzwonie pomiędzy żłobkami. Mimo licznych analogii pomiędzy zbroją wyrzeźbioną przez Hansa Peissera a autentycznym obiektem nie brak też różnic. Na napierśniku rzeźbiarz nie umieścił haka do podtrzymywania kopii, który znajduje się na zabytkowym uzbrojeniu. Może to wynikać $\mathrm{z}$ uproszczeń zastosowanych przez artystę ${ }^{33}$. Natomiast odwrotnie jest ze skrzydłem płotu nara-

\footnotetext{
${ }^{29}$ Kochanowska J. 1996, s. 108-112.

${ }^{30}$ Puławski A. 2017, s. 81.

${ }^{31}$ Cieśla M. 2015a, s. 38.

32 Burg und Herrschaft. 2010, s. 131, 133.

${ }^{33}$ Puławski A. 2017, s. 81.
} 
miennika, który widnieje na epitafium a brak go na zachowanej zbroi. To następna wskazówka na posiadanie przez Bogusława $\mathrm{X}$ garnituru zbroi.

Trudno wnioskować na temat konstrukcji tej zbroi. Philipp Hainhofer określił ją jako Kürass, czyli Küriss ${ }^{34}$. Słowo to pochodzi od włoskiego terminu Corazza $i$ oznacza pełną zbroję jeździecką, która służyła jako osłona rycerza walczącego konno długą kopią. Jej cechą charakterystyczną był hak do podtrzymywania kopii (Rüsthaken) umieszczony na prawej stronie napierśnika, który był tu szeroko wcięty, z uwagi na grubość kopii ${ }^{35}$.

Podobieństwo pomiędzy uzbrojeniem przedstawionym na omawianej płaskorzeźbie a zachowanym egzemplarzem pozwala przypuszczać, że mamy do czynienia z tą samą zbroją. Poświadczają to także przekazy pisane. Najcenniejsza wzmianka pochodzi z dziennika podróży do Frankonii, Saksonii, Marchii Brandenburskiej i na Pomorze augsburskiego kupca, bankiera, dyplomaty i kolekcjonera Filipa Hainhofera. Pod datą 25 sierpnia 1617 r. odnotował on przechowywanie w kaplicy na Zamku Książąt Pomorskich w Szczecinie pięciu zbroi. Miały one być zawieszone wraz z chorągwiami na filarach przy krypcie z pochówkami zmarłych Gryfitów. Jedną ze zbroi umieszczono dla Bogusława X, Jerzego I i Barnima XI (IX). Cztery pozostałe zawieszono kolejno dla Jana Fryderyka, Barnima XII (X), Kazimierza IX (VII) oraz Bogusława XIII ${ }^{36}$. Dla niniejszych rozważań istotna jest pierwsza z wymienionych zbroi. Ze względu na umocowanie jej nad kryptą z pochówkami trzech wyżej wymienionych władców, trzeba ją traktować jako należącą do któregoś z tych książąt. Biorąc pod uwagę czas, gdy żyli wymienieni Gryfici, tylko oni bowiem mogli używać zbroi z napierśnikiem bombiastym ${ }^{37}$.

Po wymarciu książąt pomorskich i podziale Pomorza pomiędzy Szwecję i Brandenburgię, na skutek pokoju westfalskiego 24 października 1648 r., wspomnianych pięć zbroi nadal znajdowało się w kaplicy. Dopiero w roku 1731 król pruski, Fryderyk Wilhelm I, wywiózł je jako trofea wojenne do zbrojowni w Berlinie ${ }^{38}$. W $1961 \mathrm{r}$. Hellmuth Bethe opublikował informację, że syn króla Fryderyka Wilhelma I — Fryderyk II sprzedał uzbrojenie w Londynie ${ }^{39}$. Stwierdzenie to było powtarzane w literaturze przedmiotu ${ }^{40}$. Ze względu na uderzające podobieństwo pomiędzy zbroją, w której Hans Peisser wyrzeźbił postać Bogusława X na epitafium znajdującym się do 1945 r. w kaplicy zamkowej w Szczecinie, a zbroją ze zbiorów Muzeum w Berlinie, teza Hallmutha Bethego wydaje się być chybiona. Być może tylko część uzbrojenia o pomorskiej proweniencji opuściła wówczas obecną stolicę Niemiec.

34 Hainhofer F. 1834, s. 19.

${ }^{35}$ Cieśla M. 2015b, s. 14, 45, ryc. 19. Konstrukcję tego typu zbroi zadokumentowano w powstałym w Augsburgu w latach 1548-1563, a obecnie przechowywanym w Württembergische Landesbibliothek Stuttgart, szkicowniku dekoracji zbroi autorstwa Jörga Sorga (1522-1603) (zbroja typu Küriss swój rodowód miała w mediolańskich warsztatach płatnerskich na początku XV w., gdzie określana była jako quattrocenta). Zbroja ta składała się z hełmu zamkniętego z przyczepionym kołnierzem z plecionki kolczej (był on zastępowany przez łepkę bądź szturmak), napierśnika $\mathrm{z}$ hakiem na kopię i przymocowanymi taszkami, naplecznika $\mathrm{z}$ folgowaną ochroną lędźwi, asymetrycznych naramienników ze skrzydełkami oporowymi dla ochrony szyi, opach, nałokietników i zarękawi, rękawic, sztywnych nabiodrków, nakolanników, nagolenic i trzewików. Küriss wzmocniony był dodatkowymi elementami: napierśnikiem wierzchnim zakładanym na lewy naramiennik, wzmocnieniem ze skrzydłem oporowym oraz mniejszym na prawym, wzmocnieniami na nałokietniki (mniejszy na prawym), lewą rękawicą pięściową oraz montowanym na hełmie wzmocnieniem czoła, Cieśla M. 2015b, s. 14.

${ }^{36}$ Hainhofer F. 1834, s. 19.

${ }^{37}$ Puławski A. 2017, s. 79-80. W przeszłości Autor dopuszczał możliwość, że zbroja, w której został wyrzeźbiony Bogusław X na epitafium z połowy XVI w., należała do Jerzego I, por. Puławski A. 2017, s. 81.

38 Album Pommerscher. 1899, s. 28; Kochanowska J. 1992a, s. 227.

39 Bethe H. 1961, s. 159.

40 Makała R. 2013, s. 41, przyp. 73; Puławski A. 2017, s. 78. 


\section{KATALOG}

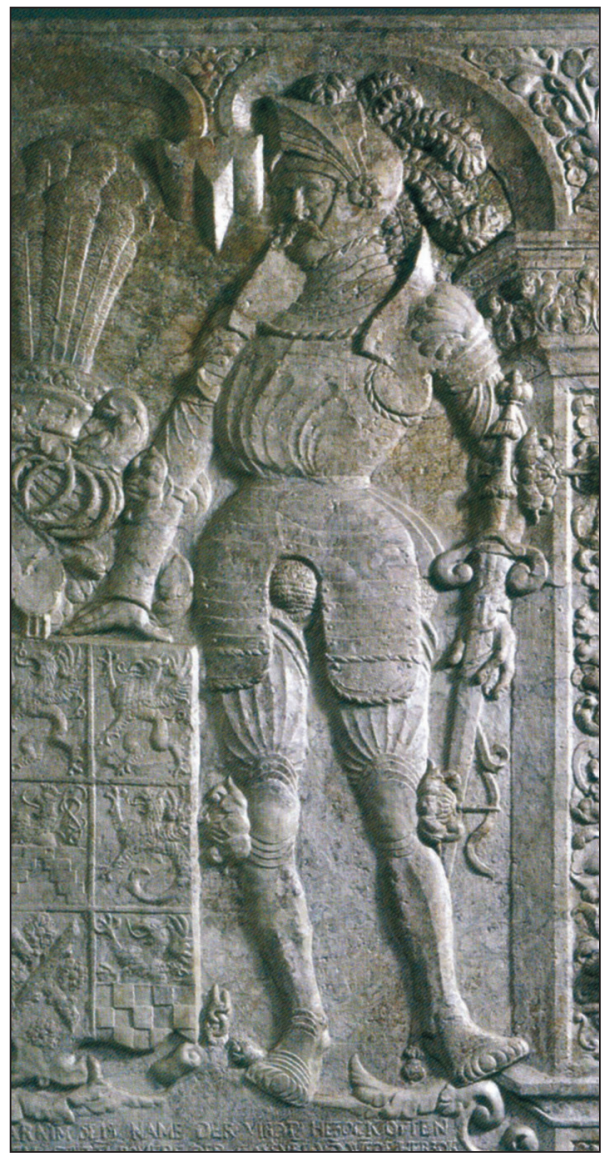

Ryc. 1. Barnim III. Płyta fundacyjna z $1543 \mathrm{r}$. (za: Krasnodębska K. 2013, ryc. 56)

Fig. 1. Barnim III. A foundation plaque from 1543 (after: Krasnodębska K. 2013, fig. 56)
1. Barnim III (przed 1300-1368), książę szczeciński (1344-1368) (ryc. 1).

Płyta fundacyjna, kamienna, płaskorzeźba. Pierwotnie z zamku Oderburg, obecnie w północnym skrzydle Zamku Książąt Pomorskich w Szczecinie.

Data powstania: $1543 \mathrm{r}$.

Książę stoi w hełmie, bez rękawic, wsparty prawą ręką na tablicy herbowej, lewą na rękojeści broni siecznej. Zbroja płytowa, maksymiliańska. Pięciofolgowy obojczyk, napierśnik bombiasty $z$ hakiem do mocowania kopii oraz trzyfolgowym fartuchem na stałe połączonym z sześciofolgowymi, zaokrąglonymi u dołu taszkami, zdobiony po brzegach motywem sznura. Na folgach fartucha i taszek widoczne główki nitów. Pomiędzy taszkami koszula kolcza tworząca ochronę genitaliów — saczek. Naramienniki z płotem, zdobienie reliefami, opachy trzyfolgowe u góry, nałokietnik i zarękawie. Nabiodrki, nakolanki z trzema folgami górnymi i dolnymi, nagolenice i trzewiki typu „krowi pysk". Cała zbroja zdobiona kanelurami. Nałokietniki i nakolanniki ozdobione antykizującymi motywami w postaci kwiatu z kolcem. Hełm armet zdobiony pióropuszem, z uniesioną zasłoną, typu ,wróbli dziób”.

Literatura: Lemcke H. 1909, s. 19-21; Glińska M. 1969, s. 307; Glińska M. 1973, s. 312-314; Glińska M. 1990, s. 80; Łopuch W. 2002, s. 167; Kochanowska J., Bellamann B., Wartenberg H. 2007, s. 13-14; Krasnodębska K. 2013, s. 64-65; Łuczak M. 2013, s. 191; Puławski A. 2016b, s. 181-232; Łopuch M. 2017, s. 27. 
2. Filip I (1515-1560), książę pomorski (1531-1532), książę wołogoski (1532-1560) (ryc. 2).

Płyta fundacyjna, kamienna, płaskorzeźba, autorstwa Hansa Schencka zwanego Scheußlich. Pierwotnie na zamku we Wkryujściu (Ueckermünde), obecnie w Muzeum Narodowym w Szczecinie.

Data powstania: $1546 \mathrm{r}$.

Fundator przedstawiony w półpostaci, w kapeluszu dekorowanym pióropuszem, z podwójnym łańcuchem z medalionem, przepasany szarfą zawiązaną na węzeł, na której zawieszone są po prawej stronie sztylet, a po lewej miecz. Prawa ręka księcia spoczywa na biodrze, lewa na rękojeści broni siecznej. Zbroja płytowa, maksymiliańska. Trzyfolgowy kanelowany obojczyk, napierśnik bombiasty z krótkim fartuchem, który na stałe połączony jest z taszkami. Widoczny saczek. U góry napierśnik wydaje się być ścięty poziomo, po prawej stronie - hak pod kopię. Naramienniki z płotem, opachy trzyfolgo-

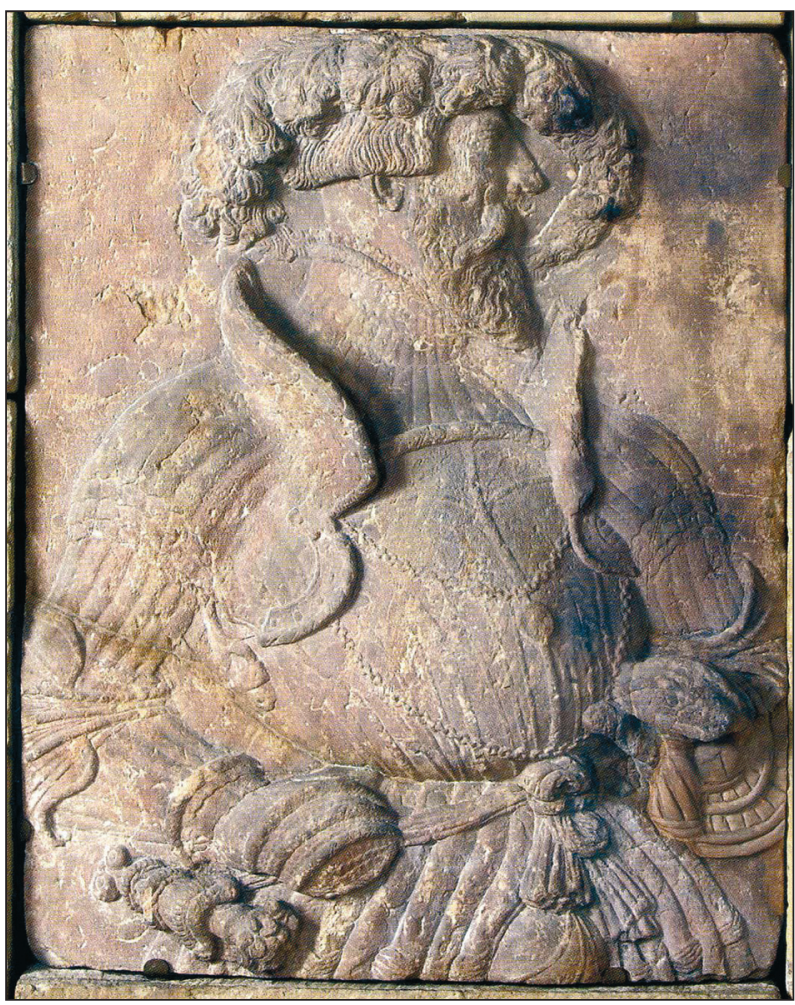

Ryc. 2. Filip I. Płyta fundacyjna z 1546 r. (za: Złoty wiek Pomorza. 2013, ryc. 163)

Fig. 2. Phillip I. A foundation plaque from 1546 (after: Złoty wiek Pomorza. 2013, fig. 163) we u góry, nałokietniki ze skrzydełkami otwartymi, zarękawia i rękawice mitynki z klepsydrowatymi mankietami. Zbroja zdobiona kanelurami.

Literatura: Wielokrotnie publikowana i omawiana, m.in.: Kugler F. 1840, s. 149, 231; Lemcke H. 1900a, s. 336-337; Bethe H. 1937a, s. 18; Bethe H. 1937b, s. 37; Glińska M. 1969, s. 330; Glińska M. 1973, s. 319-322; Glińska M. 2003, s. 277-278; Kochanowska J. 1996, s. 119, 121; Kochanowska J., Bellman B., Wartenberg H. 2007, s. 18; Łopuch W. 2002, s. 169; Złoty wiek Pomorza. 2013, s. 195-202; Puławski A. 2016b, s. 181-232; Puławski A. 2017, s. 79. 


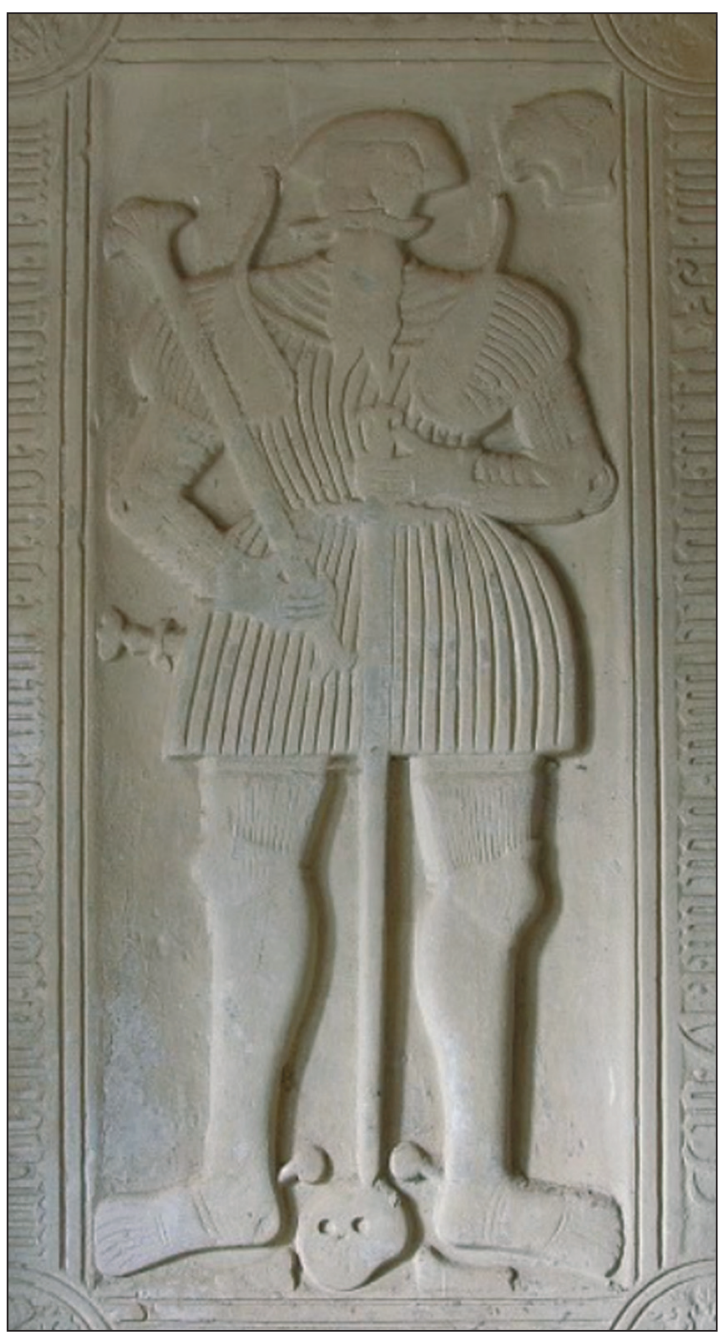

Ryc. 3. Arent von Wopersnow. Płyta nagrobna z 1549 r. (za: Puławski A. 2016b, ryc. 4)

Fig. 3. Arent von Wopersnow. A tombstone from 1549 (after: Puławski A. 2016b, fig. 4)
3. Arent von Wopersnow (?-1548), szlachcic pomorski (ryc. 3).

Płyta nagrobna, kamienna, płaskorzeźba. W kościele pw. Podwyższenia Krzyża Świętego w Stanominie (pow. białogardzki).

Data powstania: $1549 \mathrm{r}$.

Zmarły leży bez nakrycia głowy, w prawej ręce trzyma broń obuchową (?), lewa spoczywa na rękojeści miecza, który ułożony jest na ciele szlachcica od tułowia w dół. Widoczna rękojeść sztyletu. Zbroja płytowa, maksymiliańska. Obojczyk pięciofolgowy, napierśnik bombiasty, spódniczka. Naramiennik z płotem, opachy folgowane, nałokietniki, zarękawia i rękawice palczaste z klepsydrowatymi mankietami. Ochronę nóg stanowią: nabiodrki, nakolanki, nagolenice i trzewiki typu „krowi pysk”. Do trzewików przymocowane ostrogi o okrągłych bodźcach. Zbroja zdobiona kanelurami. Obok głowy szlachcica widoczny hełm o nierozpoznanej konstrukcji.

Literatura: Böttger L. 1890, s. 45; Glińska M. 1973, s. 326, 328; Puławski A. 2016b, s. 181-232. 
4. von Kameke (?-ok. 1550), nieznany z imienia szlachcic pomorski (ryc. 4).

Płyta nagrobna, kamienna, płaskorzeźba. Niezachowana. Dawniej w kościele w Łasinie (pow. koszaliński).

Data powstania: $1550 \mathrm{r}$.

Szlachcic przedstawiony w obecności żony, w lekkim rozkroku, zwrócony w lewo, bez nakrycia głowy i bez rękawic. W prawej ręce trzyma regiment, lewa spoczywa na rękojeści przypiętej do pasa broni siecznej. Przy prawym boku widoczny sztylet. Zbroja płytowa. Obojczyk, napierśnik bombiasty, spódniczka, która zdobiona jest kanelurami. Naramienniki z płotem, opachy pięciofolgowe, nałokietniki i zarękawia. Szlachcic ubrany w nabiodrki, nakolanniki i nagolenice. Zbroja wyposażona w saczek. Zachowana dokumentacja fotograficzna nie pozwala na identyfikację trzewików.

Literatura: Böttger L. 1889, s. 88-89; Glińska M. 1973, s. 334-335; Puławski A. 2016b, s. 181-232; Puławski A. 2017, s. 81 .

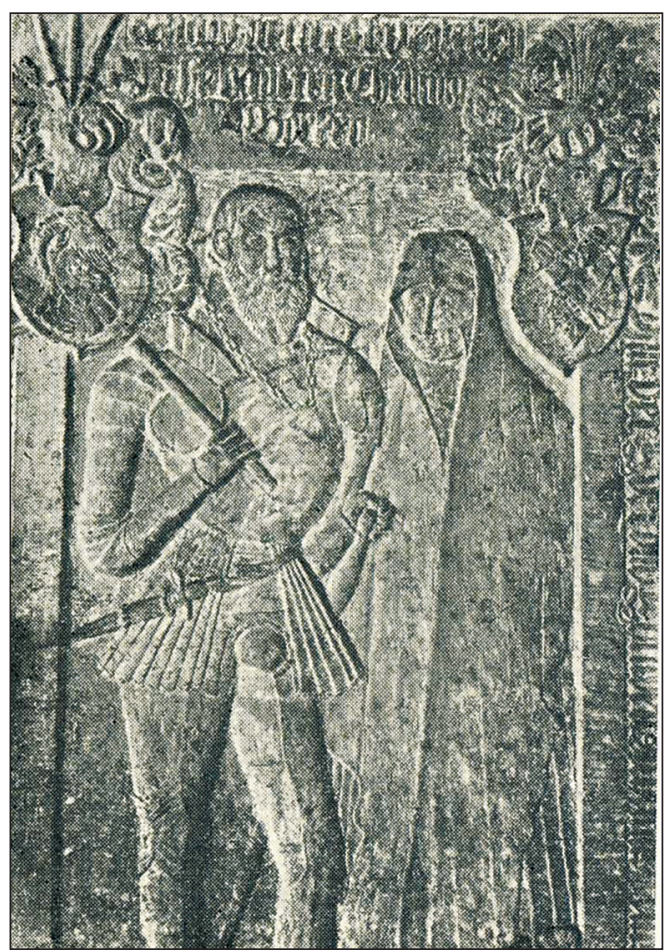

Ryc. 4. von. Kameke. Płyta nagrobna z 1550 r. (za: Glińska M. 1973, ryc. 16)

Fig. 4. von. Kameke. A tombstone from 1550 (after: Glińska M. 1973, fig. 16)

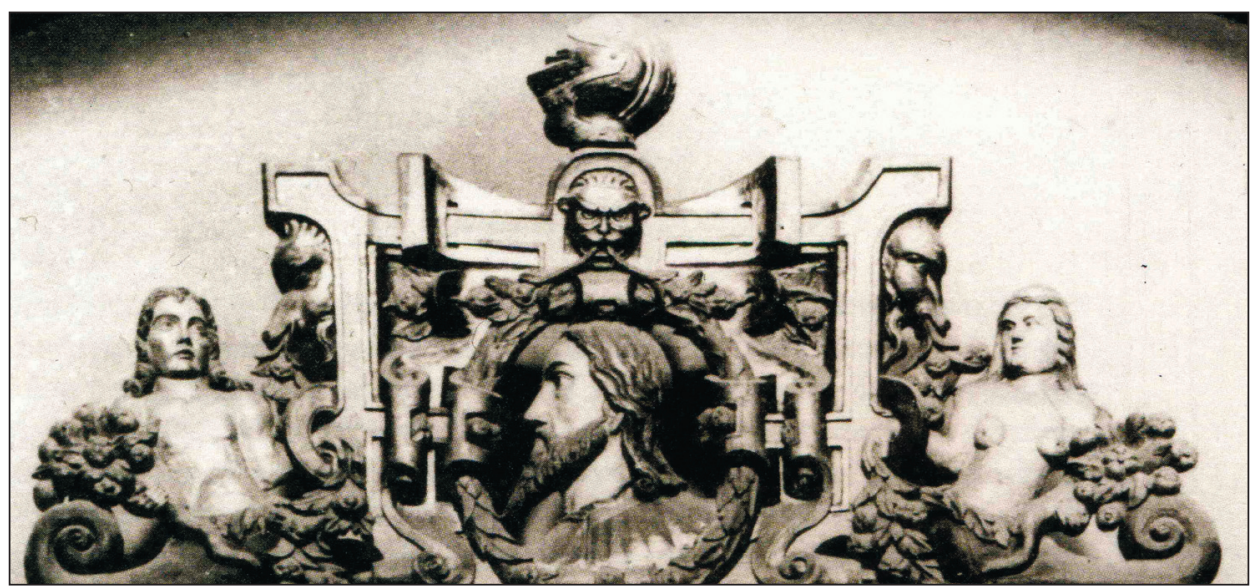



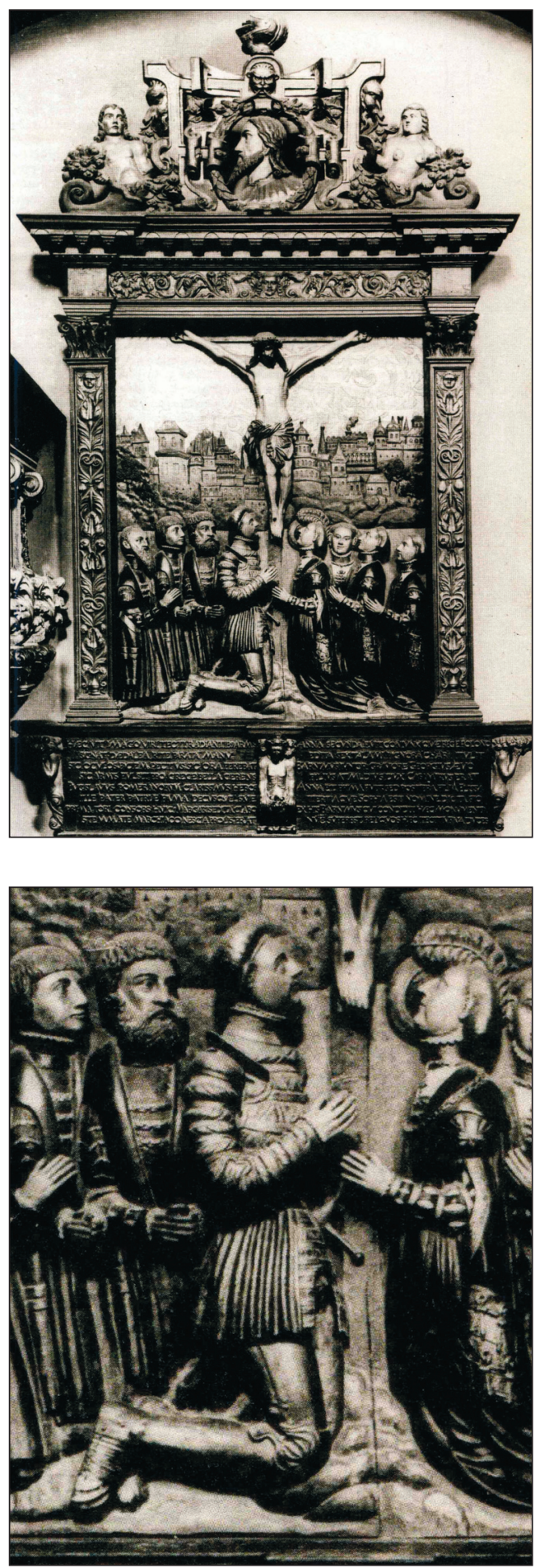

5. Bogusław X (1454-1523), książę szczeciński (1474-1523), książę słupski (1474-1478), książę rugijski (1478-1478), książę wołogoski (1478-1523), książę pomorski (1478-1523) (ryc. 5a, 5b).

Epitafium drewniane, płaskorzeźba, autorstwa Hansa Peissera. Pierwotnie w kościele zamkowym w Szczecinie, obecnie zaginione.

Data powstania: ok. $1550 \mathrm{r}$.

Adorator klęczy z modlitewnie złożonymi rękoma, bez rękawic. Zbroja płytowa, kostiumowa. Obojczyk, napierśnik bombiasty, zdobiona kanelurami spódniczka z odjętymi połami. Zauważalny prawy naręczak: naramiennik z płotem, opacha czterofolgowa, nałokietnik ze skrzydełkami otwartymi i zarękawie. Zarówno napierśnik, jak i naręczak zdobione dekoracją tzw. dmuchaną i ciętą. Nabiodrki - zauważalny tylko prawy nakolanek, nagolenice i trzewiki typu „krowi pysk". Przy lewym boku księcia przypięta broń sieczna. Na zwieńczeniu epitafium hełm zamknięty, o kolistym dzwonie, niskim grzebieniu i z opuszczoną zasłoną typu ,wróbli dziób", mocowaną za pomocą nitów (ryc. 5b). Na kołnierzu także zauważalne nity.

Literatura: Lemcke H. 1909, s. 70-71, 73; Bethe H. 1937b, s. 32, 110-113; Kochanowska J. 1992b, s. 131; Kochanowska J. 1996, s. 110-113; Łopuch W. 2002, s. 178; Wisłocki M. 2002, s. 223; Glińska M. 2003, s. 279-280; Łuczak M. 2013, s. 210-211, 213; Makała R. 2013, s. 19, 22; Puławski A. 2016b, s. 181-232; Puławski A. 2017, s. 77-97; Łopuch M. 2017, s. 20-21.

$\uparrow$ Ryc. 5a. Bogusław X. Epitafium z ok. 1550 r. (za: Łopuch M. 2017, ryc. 7)

$\uparrow$ Fig. 5a. Bogusław X. An epitaph from c. 1550 (after: Łopuch M. 2017, fig. 7)

na stronach 432 i 433

$\leftarrow$ Ryc. 5b. Detale epitafium Bogusława X z ok. 1550 r. (za: Łopuch M. 2017, ryc. 7)

on pages 432 and 433

$\leftarrow$ Fig. 5b. Details of Bogusław X's epitaph from c. 1550 (after: Łopuch M. 2017, fig. 7) 
6. Reimer von Wolde (?-1559), szlachcic pomorski, amtmann domeny Klempenow i Treptow (ryc. 6).

Płyta nagrobna, kamienna, płaskorzeźba. Niezachowana. Przed 1945 w kościele pw. św. Marii w Anklam (pow. Vorpommern-Greifswald).

Data powstania: $1559 \mathrm{r}$.

Przedstawiony jako rycerz zwrócony lekko w lewą stronę. $\mathrm{W}$ prawej ręce trzyma kopię, lewa niewidoczna. Zbroja płytowa, maksymiliańska. Trzyfolgowy obojczyk, napierśnik bombiasty z dwufolgowym fartuchem, który na stałe połączony jest z dwufolgowymi taszkami. Między taszkami zauważalny saczek. Naramienniki z płotem. Opachy niewidoczne. Nałokietnik, zarękawie i rękawica mitynka z klepsydrowatym mankietem. Nabiodrki, nakolanki z jedną folgą u góry i u dołu oraz ze skrzydełkami. Nagolenice i trzewiki typu „krowi pysk”. Widoczna osłona na genitalia. Rycerz ma założony hełm zamknięty lub armet, $\mathrm{z}$ uniesioną zasłoną typu „wróbli dziób” dekorowany piórami. Na pasie przy lewym boku mężczyzny przypięta broń sieczna.

Literatura: Kugler F. 1854, s. 282; Lemcke H. 1899, s. 127-129; Wisłocki M. 2005, s. 207; Puławski A. 2016b, s. 181-232 .

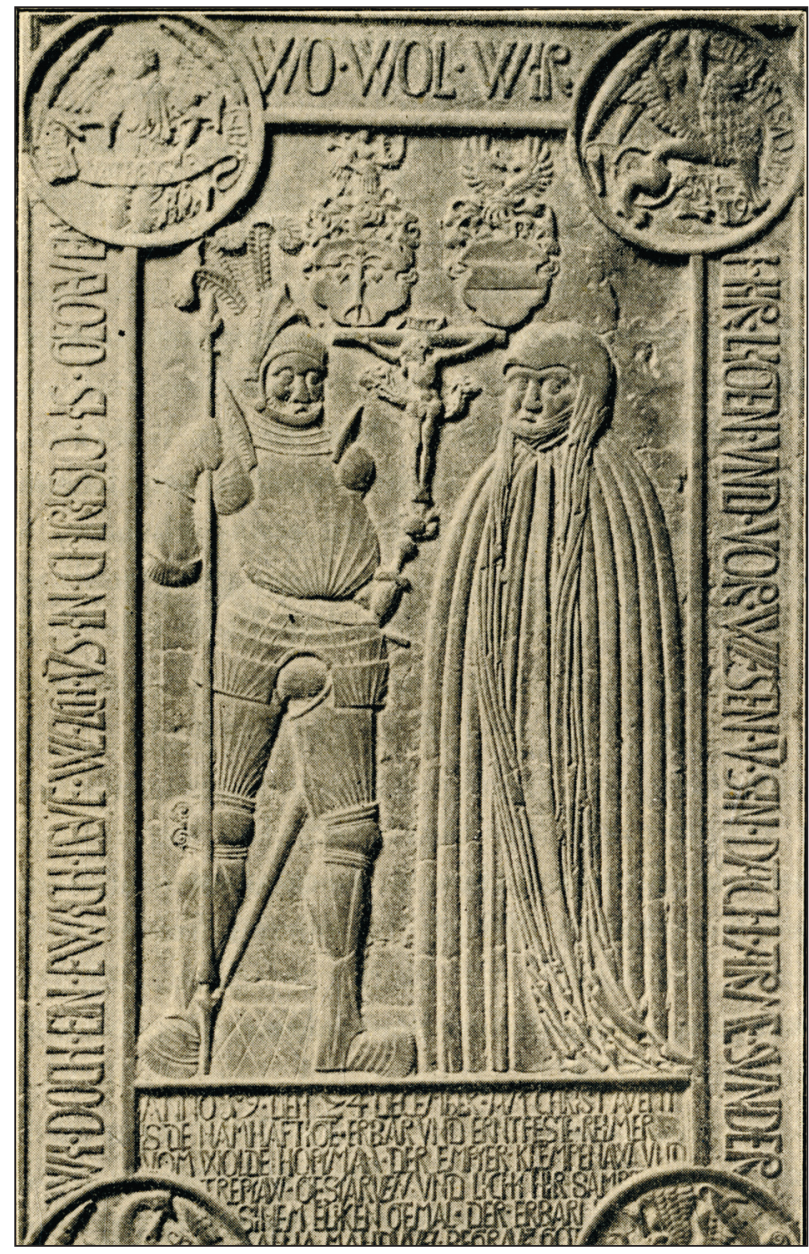

Ryc. 6. Reimer von Wolde. Płyta nagrobna z 1559 r. (za: Lemcke H. 1899, ryc. 35)

Fig. 6. Reimer von Wolde. A tombstone from 1559 (after: Lemcke H. 1899, fig. 35) 


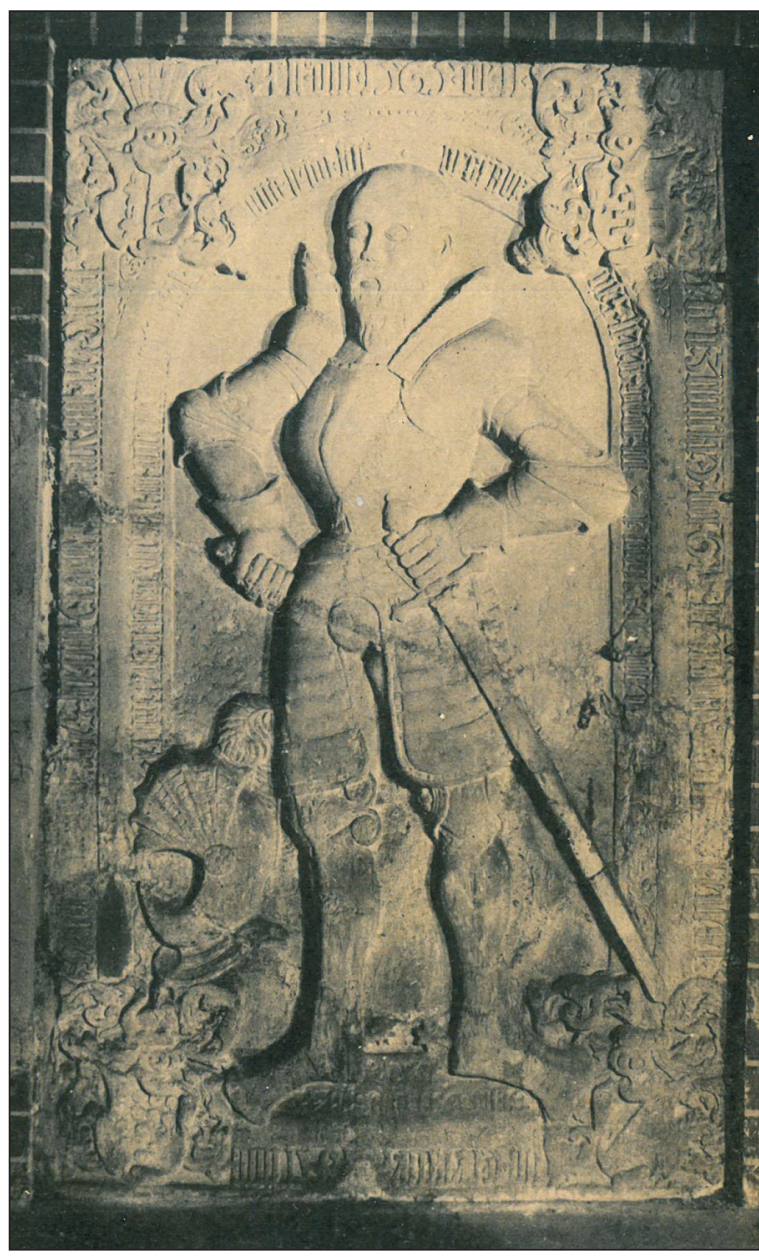

Ryc. 7. Achim von Maltzahn. Płyta nagrobna z 1565 r. (za: Lemcke H. 1898, ryc. 12)

Fig. 7. Achim von Maltzahn. A tombstone from 1565 (after: Lemcke H. 1898, fig. 12)
7. Achim von Maltzahn (1481-1565), szlachcic pomorski, marszałek książąt szczecińskich (ryc. 7).

Płyta nagrobna, kamienna, płaskorzeźba. W kościele w Gültz (pow. Mecklenburgische Seenplatte). Dawniej w kościele pw. św. Bartłomieja w Demmin.

Data powstania: $1565 \mathrm{r}$.

Przedstawiony rycerz zwrócony lekko w prawą stronę, $\mathrm{z}$ gołą głową. Lewą ręką trzyma uchwyt sztyletu, zaś prawą miecza. Obojczyk, napierśnik bombiasty z krótkim fartuchem, który na stałe łączy się z ośmiofolgowymi taszkami. Pomiędzy taszkami saczek. Naramienniki z płotem, opachy folgowane, nałokietniki z jedną folgą górną i jedną dolną oraz skrzydełkami zamkniętymi, zarękawia, rękawice palczaste $\mathrm{z}$ mankietami ze sztylptami. Nabiodrki niewidoczne. Nakolanki ze skrzydełkami, nagolenice, trzewiki typu „krowi pysk”. Ostrogi z gwieździstymi bodźcami. Obok stóp rycerza leży hełm zamknięty lub armet $\mathrm{z}$ uniesiona zasłona typu „kowalski miech” i kołnierzem. Hełm dekorowany pióropuszem.

Literatura: Lemcke H. 1898, s. 14; Glińska M. 1973, s. 336; Buske T. 2004, s. 25; Puławski A. 2016b, s. $181-232$. 


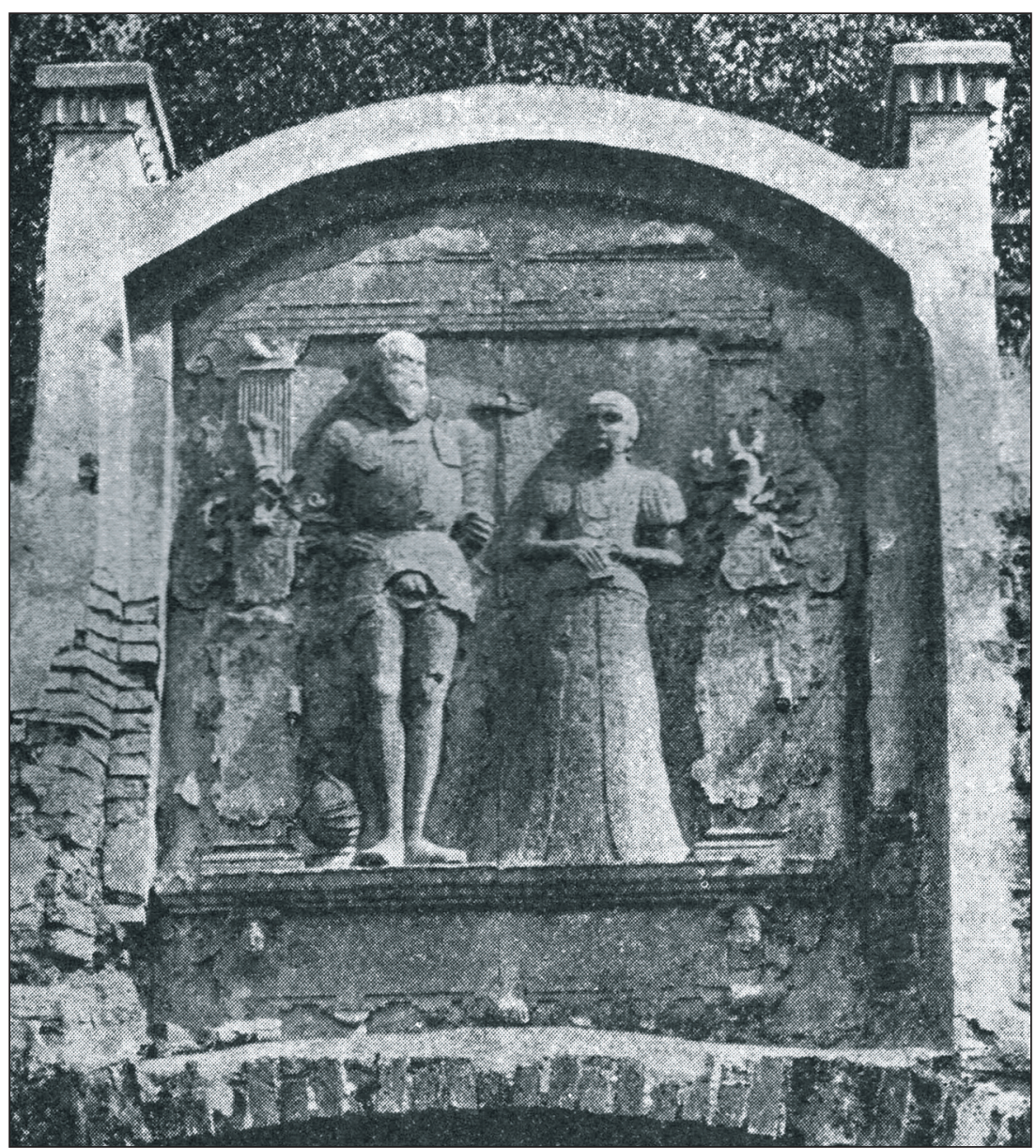

Ryc. 8. Ulrich I von Schwerin. Płyta fundacyjna z 1567 r. (za: Lemcke H. 1899, ryc. 112)

Fig. 8. Ulrich I von Schwerin. A foundation plaque from 1567 (after: Lemcke H. 1899, fig. 112)

8. Ulrich I von Schwerin (?-1576), szlachcic pomorski, wójt książęcy (ryc. 8).

Płyta fundacyjna, kamienna, płaskorzeźba. Nad bramą wjazdową na zamku w Spantekow (pow. Vorpommern-Greifswald).

Data powstania: $1567 \mathrm{r}$.

Rycerz stoi obok żony, z gołą głową, bez rękawic. Prawa ręka spoczywa na biodrze, zaś lewa na uchwycie miecza lub rapiera. Zbroja płytowa. Obojczyk, napierśnik bombiasty z fartuchem połączonym z taszkami, między którymi widać saczek. Naramienniki z płotem, opachy czterofolgowe. Nałokietniki, zarękawia niewidoczne. Ochronę nóg stanowią nabiodrki, nakolanki z dużymi, marszczonymi do środka skrzydełkami (zauważalne tylko na prawym), nagolenice i trzewiki. Obok lewej nogi rycerza leży hełm zamknięty lub armet z opuszczoną zasłoną typu „kowalski miech” i grzebieniem.

Literatura: Lemcke H. 1899, s. 243-247; Glińska M. 1973, s. 359; Mohr L. 2007, s. 46-65; Puławski A. 2016b, s. 181-232. 


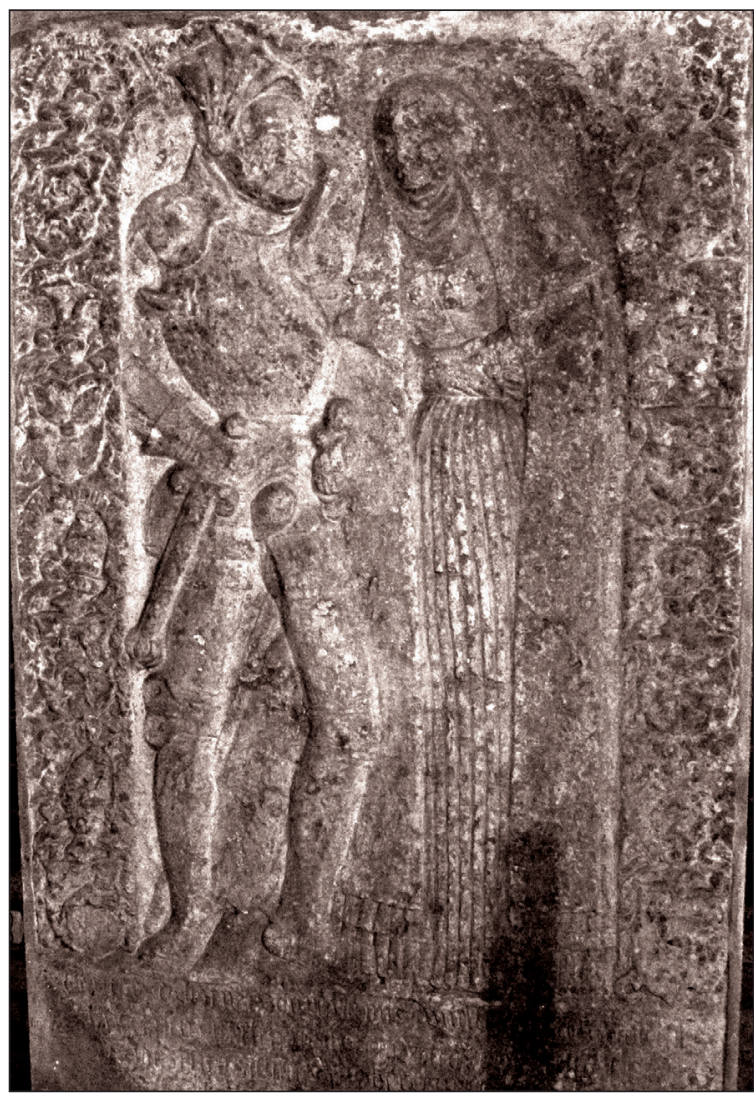

Ryc. 9. Wolf von Borcke. Płyta nagrobna z 1569 r. (fot. A. Puławski)

Fig. 9. Wolf von Borcke. A tombstone from 1569 (photo by A. Puławski)
9. Wolf von Borcke (?-1556), szlachcic pomorski, marszałek dworu, radca książęcy, landwójt gryficki, radca i landwójt świdwiński (ryc. 9).

Płyta nagrobna, kamienna, płaskorzeźba. W kościele parafialnym pw. św. Klary w Dobrej (pow. łobeski).

Data powstania: $1569 \mathrm{r}$.

Rycerz stoi obok swojej małżonki, jego prawa ręka spoczywa na rękojeści sztyletu, a lewa na rękojeści miecza, które przypięte są do pasa. Zbroja płytowa. Obojczyk, napierśnik bombiasty, $\mathrm{z}$ hakiem do mocowania kopii i fartuchem połączonym bezpośrednio z trzyfolgowymi taszkami. Pomiędzy taszkami saczek. Naramienniki z płotem, opachy folgowane, nałokietniki niewidoczne, zarękawie zauważalne tylko na prawej ręce, rękawice mitynki z klepsydrowatymi mankietami. Nabiodrki, nakolanki folgowane z dużymi, marszczonymi do środka skrzydełkami, nagolenice, trzewiki typu „krowi pysk”. Ostrogi o gwieździstych bodźcach. Postać w hełmie zamkniętym lub armecie $\mathrm{z}$ uniesioną zasłoną typu „kowalski miech”.

Literatura: Lemcke H. 1910, s. 161; Glińska M. 1973, s. 334, 336; Brzustowicz B.W. 2006, s. 210-211; Kochanowska J. 2011, s. 139; Puławski A. 2016b, s. 181-232. 
10. Jacob von Küssow (?-1586), szlachcic pomorski, kanclerz, nadmarszałek, amtmann Usedom i Pudagla (ryc. 10).

Płyta nagrobna, kamienna, płaskorzeźba. W kościele pw. św. Piotra w Benz (pow. Vorpommern-Greifswald).

Data powstania: $1586 \mathrm{r}$.

Rycerz przedstawiony w pełnej postaci, z odkrytą głową, bez rękawic. W prawej ręce trzyma broń obuchową, lewa ręka wsparta na biodrze. Zbroja płytowa. Czterofolgowy obojczyk, napierśnik bombiasty z kilkufolgowym fartuchem, który połączony jest $\mathrm{z}$ taszkami. $\mathrm{Na}$ lewym naramienniku przymocowany dodatkowy naramiennik wzmacniający z płotem. Opachy czterofolgowe u góry, nałokietniki ze skrzydełkami zamkniętymi, zarękawia. Z prawej strony zauważalna tarczka opachowa. Ochronę nóg stanowią nabiodrki, folgowane nakolanki (ze skrzydełkami wewnętrznymi ?), nagolenice i trzewiki. Przy lewej nodze rycerza leży hełm zamknięty z kołnierzem i uniesioną zasłoną typu „wróbli dziób”. Przy lewym boku rycerza przypięta broń sieczna.

Literatura: Lemcke H. 1900b, s. 349-352; Glińska M. 1973, s 339; Die Bau- und Kunstdenkmale in Mecklenburg-Vorpommern. 1995,

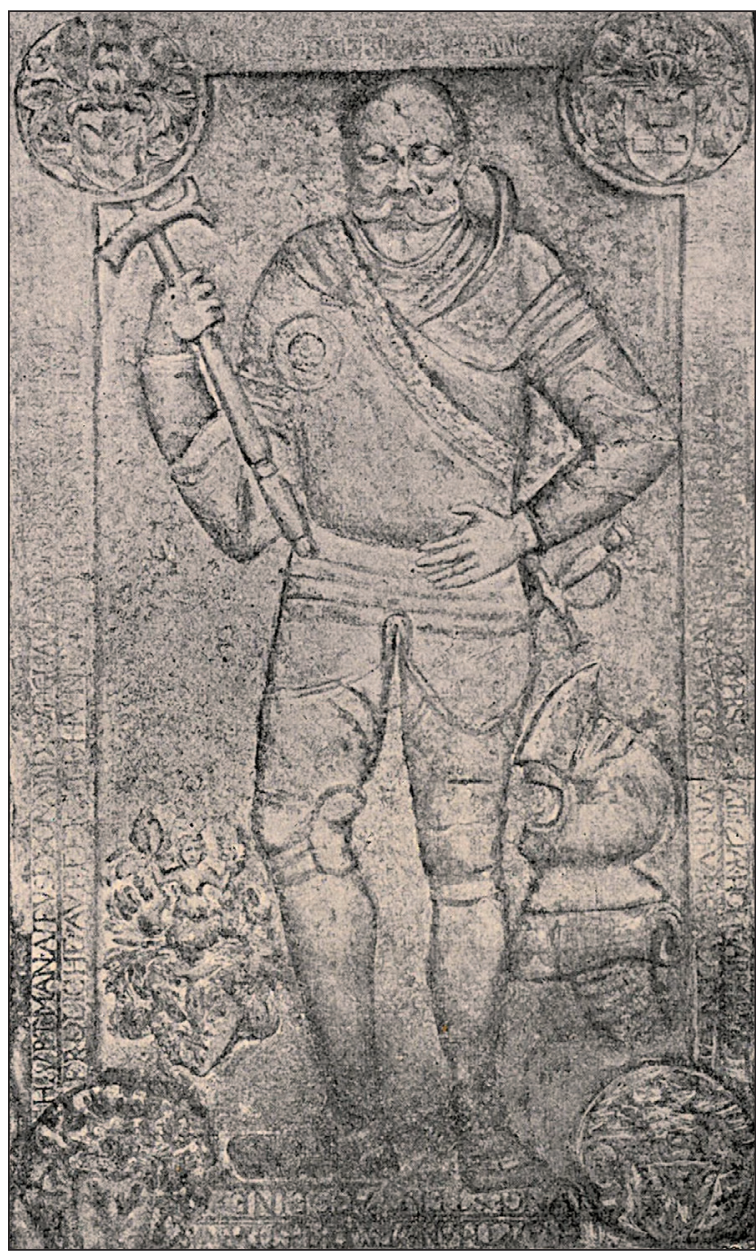

Ryc. 10. Jacob Küssow. Płyta nagrobna z 1586 r. (za: Lemcke H. 1900a, ryc. 1)

Fig. 10. Jacob Küssow. A tombstone from 1586 (after: Lemcke H. 1900a, fig. 1)

s. 278-279; Handbuch der deutschen Kunstdenkmäler. 2000, s 59-60; Puławski A. 2016b, s. $181-232$. 


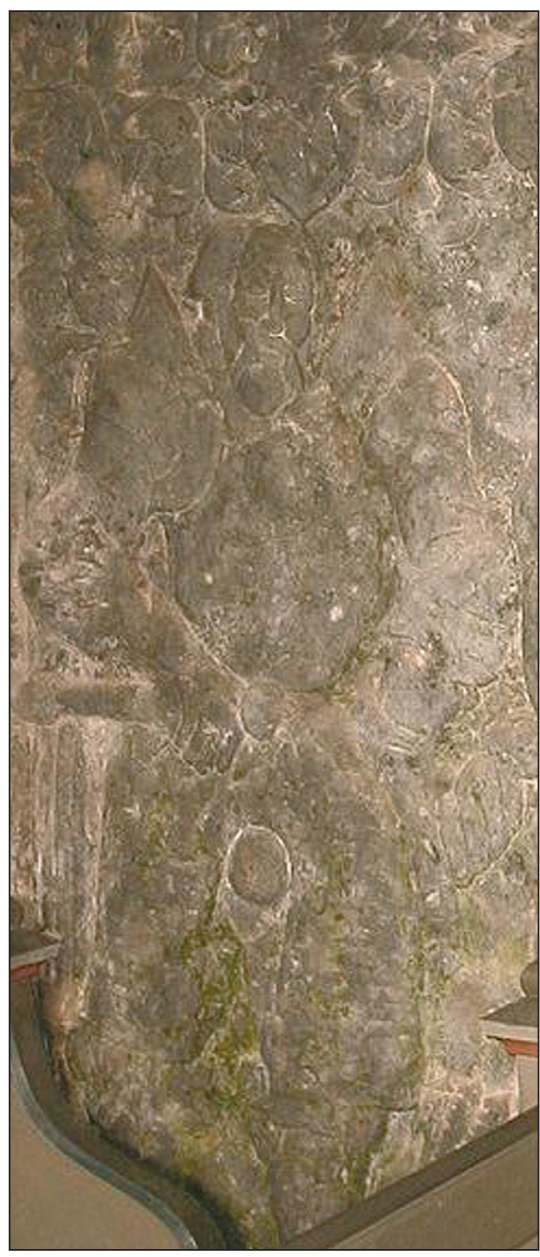

Ryc. 11. Roloff von Owstin.

Płyta nagrobna z $1591 \mathrm{r}$. (za: Puławski A. 2016b, ryc. 19)

Fig. 11. Roloff von Owstin. A tombstone from 1591

(after: Puławski A. 2016b, fig. 19)
11. Roloff von Owstin (?-1591), szlachcic pomorski (ryc. 11).

Płyta nagrobna, kamienna, płaskorzeźba. W kościele w Quilow (pow. Vorpommern-Greifswald).

Data powstania: $1591 \mathrm{r}$.

Szlachcic przedstawiony w pełnej postaci, lekko zwrócony w lewo, bez nakrycia głowy. Prawa ręka spoczywa na rękojeści puginału, lewa na biodrze. Do pasa przypięta broń sieczna. Obojczyk, napierśnik bombiasty z fartuchem bezpośrednio połączonym z folgowanymi taszkami. Pomiędzy nimi widoczny saczek. Naramienniki z płotem, opachy z trzema folgami u góry, nałokietniki ze skrzydełkami zamkniętymi, zarękawia i rękawice palczaste z mankietami ze sztylptem. Ochronę nóg stanowią nabiodrki, nakolanki i nagolenice (trzewiki zasłonięte przez ławki do siedzenia).

Literatura: Haselberg E. 1885, s. 161-162; Handbuch der deutschen Kunstdenkmäler. 1968, s. 131; Die Bau- und Kunstdenkmale in der DDR. 1982, s. 58; Handbuch der deutschen Kunstdenkmäler. 2000, s. 429; Puławski A. 2016b, s. 181-232.

\section{Adres Autora:}

mgr Andrzej Puławski

Książnica Stargardzka

ul. Mieszka I 1

73-110 Stargard

ab.pulawski@onet.eu

https://orcid.org/0000-0001-8714-0396

\section{BIBLIOGRAFIA}

\section{Źródla i opracowania drukowane}

Album pommerscher. 1899. Album Pommerscher Bau- und Kunstdenkmäler, Stettin.

Bethe Hallmuth. 1937a. Die Bildnisse des pommerschen Herzogshauses, „Baltische Studien. Neue Folge", t. 39, Stettin, s. 71-99.

Bethe Hallmuth. 1937b. Die Kunst Am Hofe der pommerschen Herzöge, Berlin.

Bethe Hallmuth. 1961. Neue Funde zur Kunst am Hofe der pommerschen Herzöge, „GreifswaldStralsunder Jahrbuch", 1, s. 152-171.

Blair Claude. 1958. European Armour, circa 1066 to circa 1700, London.

Bołdyrew Aleksander. 2005. Produkcja i koszty uzbrojenia w Polsce w XVI wieku, Warszawa. 
Böttger Ludwig. 1889. Die Bau- und Kunstdenkmäler des Regierungsbezirks Köslin, t. 1: Die Kreise Köslin und Colberg-Körlin, Stettin.

Böttger Ludwig. 1890. Die Bau- und Kunstdenkmäler des Regierungsbezirks Köslin, t. 2: Kreis Belgard und Nachträge zum kreise Colberg-Körlin, Stettin.

Brzustowicz Bogdan Wojciech. 2006. Wolf von Borcke. Zapomniany pomorski czempion turniejowy?, [w:] Pomorze Militarne XII-XXI wiek, cz. 2, red. K. Kozłowski, W. Wróblewski, Szczecin, s. 201-211.

Burg und Herrschaft. 2010. Burg und Herrschaft. Eine Ausstellung des Deutschen Historischen Museums Berlin, red. R. Atzbach, S. Lüken, H. Ottomeyhem, Dresden.

Buske Thomas. 2004. St.-Bertholomaei-Kirche zu Demmin, Schwerin.

Capwell Tobias. 2015. Armour of the English Knight 1400-1450, London.

Cieśla Mariusz. 2008. Broń renesansowa na Śląsku, Racibórz.

Cieśla Mariusz. 2011. Zbroja angielska z królewskich warsztatów płatnerskich w Greenwich, [w:] Cum Arme per Aeva. Uzbrojenie indywidualne na przestrzeni dziejów, red. P. Kucypera, P. Pudło, Toruń, s. 283-316.

Cieśla Mariusz. 2015a. Napierśnik i naplecznik kostiumowy z Muzeum Wojska Polskiego w Warszawie na tle zbroi tego typu, „Studia z Dziejów Wojskowości”, t. IV, s. 9-55.

Cieśla Mariusz. 2015b. Zbroja legnicka czy zbroje legnickie - próba wyjaśnienia, Racibórz.

Die Bau- und Kunstdenkmale in der DDR. 1982. Die Bau- und Kunstdenkmale in der DDR, 3, Bezirk Neubrandenburg, red. G. Baier, Berlin.

Die Bau- und Kunstdenkmale in Mecklenburg-Vorpommern. 1995. Die Bau- und Kunstdenkmale in Mecklenburg-Vorpommern, t. 1: Vorpommersche Küstenregion mit Stralsund, Greifswald, Rügen und Usedom, red. G. Baier, Berlin.

Fuiński Zbigniew. 1988. Garnitur zbroi, „Studia do Dziejów Dawnego Uzbrojenia i Ubioru Wojskowego", cz. IX, X, s. 115-140.

Gamber Ortwin. 1975. Kolman Helmschmid, Ferdinand I. und das Tsun 'sche Skizzenbuch, „Jahrbuch der Kunsthistorischen Sammlungen in Wien”, Bd. 71, s. 9-38.

Glińska Maria. 1969. Zespół pomorskich płyt kamiennych architektoniczno-dekoracyjnych z lat około 1545-1548, „Materiały Zachodniopomorskie”, t. 15, s. 291-360.

Glińska Maria. 1973. Plastyka kamienna na Pomorzu Zachodnim w latach 1530-1640, [w:] Sztuka Pomorza Zachodniego, Warszawa, s. 305-365.

Glińska Maria. 1990. Książece fundacje w zakresie rzeźby kamiennej, [w:] Mecenat artystyczny ksiażat Pomorza Zachodniego. Materiaty z sesji Oddziału Szczecińskiego Stowarzyszenia Historyków Sztuki w Zamku Królewskim w Warszawie 22-23 listopada 1986, red. B. Filipowiak, B. Januszkiewicz, Szczecin, s. 75-102.

Glińska Maria. 2003. Wpływy niderlandzkie w sztuce Pomorza Zachodniego w czasach nowożytnych, [w:] Niderlandyzm na Śląsku $i$ w krajach ościennych, red. M. Kapustka, A. Kozieł, P. Oszczanowski, Wrocław, s. 278-290.

Gutkowska-Rychlewska Maria. 1968. Historia ubiorów, Wrocław-Warszawa-Kraków.

Hainhofer Philipp. 1834. Philipp Hainhofers Reise-Tagebuch, enthaltend Schilderungen aus Franken, Sachsen, der Mark Brandenburg und Pommern im Jahre 1617, „Baltische Studien”, t. 2, nr 2, s. 1-160.

Handbuch der deutschen Kunstdenkmäler. 1968. Handbuch der deutschen Kunstdenkmäler, red. E. Badstübner, G. Dehio, B. Becker, Berlin.

Handbuch der deutschen Kunstdenkmäler. 2000. Handbuch der deutschen Kunstdenkmäler: Mecklenburg-Verpommern, red. H.-Ch. Feldmann, G. Baier, G. Dehio, E. Gall, München.

Haselberg Ernst. 1885. Die Baudenkmäler des Regierungs-Bezirks Stralsund, t. 2: Der Kreis Greifswald, Stettin.

Kajzer Leszek. 1976. Uzbrojenie i ubiór rycerski w średniowiecznej Matopolsce w świetle źródeł ikonograficznych, Wrocław.

Kantzow Thomas. 2005. Pomerania. Kronika pomorska z XVI wieku, tłum. K. Gołda, przyp. i komentarze T. Białecki, E. Rymar, t. II, Szczecin 2005.

Kochanowska Janina. 1992a. Sarkofagi ksiażęce z krypty zamkowej, [w:] E. Cnotliwy i in., Zamek książęcy w Szczecinie, Szczecin, s. 225-241.

Kochanowska Janina. 1992b. Szczecińska rezydencja ksiażat jako pomnik rodu, [w:] E. Cnotliwy $\mathrm{i}$ in., Zamek ksiązęcy w Szczecinie, Szczecin, s. 129-145.

Kochanowska Janina. 1995. Ottarz i ambona z Sowna. Historia fundacji, peregrynacje, dziewiętnastowieczna konserwacja, dzieje najnowsze, „Przegląd Zachodniopomorski”, R. X, z. 3, s. 129-139. 
Kochanowska Janina. 1996. Kultura artystyczna na dworze ksiażat szczecińskich w XVI w., Szczecin.

Kochanowska Janina. 2000. Ottarz z Sowna i jego związi ze Stargardem, [w:] Dawny Stargard. Miasto i jego mieszkańcy. Materiały z sesji naukowej 18-19 X2000 w Stargardzie, red. M. Majewski, Stargard, s. 111-115.

Kochanowska Janina. 2011. Perty Pomorza. The Pearls of Pomerania. Die Perlen Pommerns, Szczecin.

Kochanowska Janina, Bellamann Brit, Wartenberg Heiko. 2007. Śladami ksiażą pomorskich. Auf dem Spuren der pommerchen Herze, Szczecin.

Krasnodębska Kinga. 2013. Nowożytna rzeźba kamienna na dworach ksiażą pomorskich w okresie złotego wieku Pomorza, [w:] Złoty wiek Pomorza. Sztuka na dworze ksiażat pomorskich w XVI i XVII wieku / Das goldene Zeitalter Pommerns. Kunst am Hofe der pommerschen Herze im 16. und 17. Jahrhundert, red. M. Frankowska-Makała, Szczecin, s. 61-79.

Krause Stefan. 2017. Fashion in Steel. The Landsknecht Armour of Wilhelm von Rogendorf, New Haven-London.

Kugler Franz. 1840. Pommersche Kunstgeschichte, Stettin.

Kugler Franz. 1854. Kleine Schriften, Berlin.

Lemcke Hugo. 1898. Die Bau- und Kunstdenkmäler des Regierungsbezirks Stettin, t. 1: Der Kreis Demmin, Stettin.

Lemcke Hugo. 1899. Die Bau- und Kunstdenkmäler des Regierungsbezirks Stettin, t. 2: Der Kreis Anklam, Stettin.

Lemcke Hugo. 1900a. Die Bau- und Kunstdenkmäler des Regierungsbezirks Stettin, t. 3: Der Kreis Ückermünde, Stettin 1900.

Lemcke Hugo. 1900b. Die Bau- und Kunstdenkmäler des Regierungsbezirks Stettin, t. 4: Der Kreis Usedom-Wollin, Stettin.

Lemcke Hugo. 1909. Die Bau- und Kunstdenkmäler des Regierungsbezirks Stettin, t. 14, cz. 1: Das Königliche Schloss in Stettin, Stettin.

Lemcke Hugo. 1910. Die Bau- und Kunstdenkmäler des Regierungsbezirks Stettin, t. 9: Der Kreis Naugard, Stettin.

Łopuch Maria. 2017. Funeralia pomorskich Gryfitów, [w:] Pompa funebris książat z dynastii Gryfitów, red. M. Łopuch, Szczecin, s. 9-35.

Łopuch Wojciech. 2002. Sztuka na Pomorzu, Szczecin.

Łuczak Marek. 2013. Szczecin Stare Miasto, Szczecin.

Maciejowski Maciej. 2000. Wizerunek hetmu garnczkowego w pieczęciach rycerstwa zachodniopomorskiego w pierwszej połowie XIV w. w zbiorach Muzeum Narodowego w Szczecinie, „Materiały Zachodniopomorskie", t. 46, s. 279-286.

Majewski Marcin. 2005. Ptyta nagrobna Petera von Kameke z Łasina (†1613) i jej twórca, „Koszalińskie Zeszyty Muzealne", t. 25, s. 113-124.

Makała Rafał. 2013. Sztuka w stużbie książat pomorskich w XVI i XVII wieku, [w:] Złoty wiek Pomorza. Sztuka na dworze książat pomorskich w XVI i XVII wieku. Das goldene Zeitalter Pommerns. Kunst am Hofe der pommerschen Herze im 16. und 17. Jahrhundert, red. R. Makała, Szczecin, s. 15-41.

Mohr Lutz. 2007. Klosterruine Stolpe und Burg Spantekow im Umfeld von Anklam. Zwei markante geschichtsträchtige Stätten aus dem mittelalterlichen Pommern, „Stier und Greif. Blätter zur Kultur- und Landesgeschichte in Mecklenburg-Vorpommern", t. 17, s. 46-65.

Patterson Angus. 2009. Fashion and Armour in Renaissance Europe. Proud Lookes and Brave Attire, New York.

Puławski Andrzej. 2016a. Gotyckie uzbrojenie ochronne na epitafium Zyberta (Siwerta) Grantzina z 1492 roku z kościoła NMP w Kołobrzegu, [w:] Trzebiatów - spotkania pomorskie 2015, red. J. Kochanowska, Trzebiatów, s. 97-106.

Puławski Andrzej. 2016b. Renesansowe i barokowe uzbrojenie ochronne na Pomorzu w świetle wybranych źródet ikonograficznych, ,Stargardia. Rocznik Muzeum Archeologiczno-Historycznego w Stargardzie poświęcony przeszłości i kulturze Pomorza oraz innych ziem nadbałtyckich”, t. 10, s. 181-232.

Puławski Andrzej. 2017. Zbroje książąt pomorskich z kaplicy zamkowej w Szczecinie — próba charakterystyki w oparciu o zabytki sztuki, „Stargardia. Rocznik Muzeum Archeologiczno-Historycznego w Stargardzie poświęcony przeszłości i kulturze Pomorza oraz innych ziem nadbałtyckich", t. 11, s. 77-97.

Richardson Thom. 2016. The Tower Armoury in the Fourteenth Century, Leeds.

Rymar Edward. 2004a. Wielka podróż wielkiego księcia. Wyprawa Bogusława X Pomorskiego na niemiecki dwór królewski, do Ziemi Świętej i Rzymu (1496-1498), Szczecin. 
Rymar Edward. 2004b. Wielka podróż wielkiego księcia. Wyprawa Bogusława X Pomorskiego na niemiecki dwór królewski, do Ziemi Świętej i Rzymu (1496-1498), Suplement, Szczecin.

Rymar Edward. 2005. Rodowód książat pomorskich, Szczecin.

Swaryczewski Andrzej, Fuiński Zbigniew. 1964. Napierśnik zbroi tzw. Maksymiliański ze zbiorów prywatnych w Krakowie, „Studia do Dziejów Dawnego Uzbrojenia i Ubioru Wojskowego”, t. 2, s. 5-9.

Wawrzonowska Zdzisława. 1976. Uzbrojenie i ubiór rycerski Piastów ślaskich od XII do XIV wieku, Łódź.

Wisłocki Marcin. 2002. Upamiętnienia i gloryfikacja w ewangelickiej sztuce Pomorza w XVI i XVII wieku, „Rocznik Historii Sztuki”, R. 27, s. 213-253.

Wisłocki Marcin. 2005. Sztuka protestancka na Pomorzu 1535-1684, Szczecin.

Wybranowski Dariusz. 1987. Uzbrojenie $i$ wyposażenie rycerskie na pieczęciach Gryfitów z lat 1170-1623, „Przegląd Zachodniopomorski”, t. 31, z. 2, s. 149-181.

Wybranowski Dariusz. 1993. Ksiązęta Pomorza Zachodniego na pieczęciach, Szczecin.

Wybranowski Dariusz. 2004. Wizerunek rycerski na pieczęciach książat zachodniopomorskich, rugijskich $i$ gdańskich, [w:] Najnowsze badania nad numizmatyka i sfragistyka Pomorza Zachodniego. Materiaty z konferencji naukowej 50 lat Działu Numizmatycznego Muzeum Narodowego w Szczecinie 19-20 września 2002 roku, red. G. Horoszko, Szczecin, s. 189-197.

Złoty wiek Pomorza. 2013. Złoty wiek Pomorza. Sztuka na dworze książą pomorskich w XVI i XVII wieku. Das goldene Zeitalter Pommerns. Kunst am Hofe der pommerschen Herzöge im 16. und 17. Jahrhundert, red. R. Makała, Szczecin.

Żygulski Zdzisław jun. 1972. Kostiumologia, Kraków.

Żygulski Zdzisław jun. 1982. Broń w dawnej Polsce na tle Europy i Bliskiego Wschodu, Warszawa.

Renaissance plate armour with a deep-bellied breastplate in the former Duchy of Pomerania in the light of selected works of art

The article discussed eleven works of art with images of the most prominent men of the Duchy of Pomerania, shown in suits of armour, which were among the most impressive types of wear of the epoch.

All the images are reliefs, ten of them carved in stone (Figures 1-4, 6-11; Catalogue no. 1-4, 6-11) and one in wood (Fig. 5a-5b; Cat. no. 5). Three are foundation plaques (Fig. 1-2, 8; Cat. no. 1-2, 8), seven are tombstones (Fig. 3-4, 6-7, 9-11; Cat. no. 3-4, 6-7, 9-11) and one is an epitaph (Fig. 5a-5b; Cat. no. 5). Three show dukes of Pomerania (Fig. 1-2, 5a-5b; Cat. no. 1-2, 5) and eight - Pomeranian nobles (Fig. 3-4, 6-11; Cat. no. 3-4, 6-11). Eight have survived until today (Fig. 1-3, 7-11; Cat. no. 1-3, 7-11), while the remaining three are known from archival photographs (Fig. 4-6; Cat. no. 4-6). All were intended for places treated as family memorials, such as residences or churches. Of the surviving reliefs five remain in their original locations (Fig. 3, 8-11; Cat. no. 3, 8-11) and three have been transferred (Fig. 1-2, 7; Cat. no. 1-2, 7). The images discussed in this article provide a starting point for research on plate armour in Pomerania in the early decades of the $16^{\text {th }}$ century.

All the figures are shown in plate armour with a deep-bellied breastplate, some of them in the most characteristic richly decorated Maximilian suits of armour, which reflected the men's fashion of the time. Maximilian armour is depicted in four of the cases analysed (Cat. no. 1-3, 6). Another type of armour used at the time had similarly harmonious proportions but was plain (Cat. no. 4, 7-11). The first one of these has a tucked skirt. One of the reliefs shows a costume suit of armour (Cat. no. 5).

The analysed iconographic sources bring valuable data on historical armour. The plate armour in the epitaph of Duke Bogusław X is represented in such detail that it was possible to compare it with a costume suit of armour preserved in Deutsche Historisches Museum in Berlin (inventory no. W 2327) and to conclude that the latter is the armour that used to belong to the Pomeranian Duke and was brought to Berlin in 1731 by King Frederic William I of Prussia.

Translated by Izabela Szymańska 